\title{
The Journal of the HISTORY of PHILOSOPHY
}

Editor: Richard H. Popkin, University of California-San Diego, La Jolla, California

Review Editors: Herbert W. Schnemer and A. R. Louch, Claremont Graduate School, and W. H. Werkmeister, Florida State University

INTERNational in scope, the foumal comprises articles, notes, discussions, and reviews in the major Western languages about the history of Western philosophy, broadly conceived.

Containing 128 pages in each issue, the fournal is published quarterly, in January, April, July and October. Subscription rates are: Libraries and Institutions, \$10.00; Individuals (USA and Canada), \$7.00; Individuals (Elsewhere), $\$ 5.00$; Students, $\$ 3.50$. Current copies are $\$ 2.00$ each, back copies \$3.00. Order from:

\section{JOURNAL OF THE HISTORY OF PHILOSOPHY}

Philosophy Department

University of California, San Diego

La Jolla, California 92037

\section{INQUIRY}

An Interdisciplinary Journal of Philosophy and the Social Sciences

Edited: Arne Naess and Alastair Hannay

Volume $14 \quad$ Number 3

Autumn 1971

Wants, Needs, and Liberalism

Comment

Foundations of the Liberal Make-Believe

Comment

Military Service and Moral Obligation

Comment

On the Choice between Reform and Revolution

Comment

Reform, Violence, and Personal Integrity

Comment

Arnold S. Kaufman Richard B. Brandt

Christian Bay

William E. Connolly

Hugo Adam Bedau

S. R. Doss

Kai Nielsen

Robert V. Hannaford

Gerald C. MacCallum Jr. Richard B. Brandt

Review Discussions:

The Structure and Content of Husserl's Logical Investigations Ted Honderich: Punishment: the Supposed Justifications

Robert Sokolowksi Jonathan Glover

Published quarterly by Universitetsforlaget, P.O. Box 307, Blindern, Oslo 3, Norway Annual Subscription: $\$ 7.50, £ 2.75$, postage included 


\section{CANADIAN JOURNAL OF PHILOSOPHY}

PUBLISHED BY THE CANADIAN ASSOCIATION FOR PUBLISHING IN PHILOSOPHY

Editorial Board-John King-Farlow (Alberta), Kai Nielsen (Calgary), Terence Penelhum (Calgary),William Rozeboom (Alberta) - La Redaction

VOLUME I

NUMBER 3

MARCH 1972

WAYS AND MEANS

REFERENCE AND SPATIO-TEMPORAL COORDINATES

A SCRUTINY OF REFERENCE

JUSTICE AND UTILITY

THE FIRM BUT UNTIDY CORRELATIVITY OF RIGHTS AND OBLIGATIONS

RETRIBUTIVE JUSTICE

IFS AND CANS - II

nette Baier

Charles S. Travis

Graham Nerlich

Paul Taylor

David Braybrooke

Gertrude Ezorsky

D. F. Pears

CRITICAL NOTICE OF MINNESOTA STUDIES IN THE PHILOSOPHY OF

SCIENCE Vol. IV

C. A. Hooker

Annual Subscription - Individuals \$10; Institutions \$12. - Abonnement Annuel

Subscriptions to - Roger A. Shiner (Managing Editor) - pour Abonnements

Manuscripte to - Charles G. Morgan (Executive Secretary) - pour Manuscrits

Department of Philosophy, University of Alberta, Edmonton 7, Alberta, Canodo

\section{IT'S GREEK TO THE COMPUTER}

A. Q. Morton, A. D.Winspear. Assisted by M. Levison \& B. S. Michaelson

An introduction to the use of the computer in literature

Here the classicist, the computer scientist, biblical scholar and statistician, have formed a team to study and write simply and lucidly about the new stylometrics. The latter rests on the insights and labours of the old stylometrics, but is distinguished by its study of the most common, instead of uncommon words.

It's Greek to the Computer should help to settle some very old and central issues, such as the authenticity and authorship of texts attributed to Plato, to Aristotle, to Plato and Aristotle, and to others. The fascinating question: Was there a Homer? is also dealt with in a most original and provocative way. The book will interest a wide variety of scholars and all those who relish a good historical puzzle.

128 pages

cloth $\$ 8.50$

FROM

HARVEST HOUSE LIMITED

1364 GREENE AVENUE, MONTREAL 215, P.O.

PUBLSHERS 


\title{
T H E O R I A \\ A SWEDISH JOURNAL OF PHILOSOPHY
}

\section{Edited by Göran Hermerén, Dag Prawitz and Krister Segerberg}

\author{
Volume XXXVI 1970 Part 3 \\ IN MEMORY OF ARTHUR PRIOR
}

P. T. Geach Arthur Prior: A personal impression . . . . . . . . . . ${ }_{1} 86$

Olav Flo Bibliography of the philosophical writings of A. N. Prior . . 189

Erik Stenius The semantic status of laws of logic . . . . . . . . 214

$K$. E. Trangy Deontic logic and deontically perfect worlds . . . . . 221

faakko Hintikka 'Prima facie' obligations and iterated modalities . . . 232

Bengt Hansson Deontic logic and different levels of generality . . . . 24I

C. L. Hamblin The effect of when it's said . . . . . . . . . . . . 249

Richmond $H$. Thomason Indeterminist time and truth-value gaps . . . 264

R. A. Bull An approach to tense logic . . . . . . . . . . . 282

Krister Segerberg Modal logics with linear alternative relations . . . . 30I

Dov M. Gabbay Selective filtration in modal logic . . . . . . $\cdot 323$

David Makinson A generalisation of the concept of a relational model for

modal logic ............. . . 331

Kit Fine Propositional quantifiers in modal logic . . . . . . . . . . 336

M. 7. Cresswell Classical intensional logics . . . . . . . . . . . . . 347

Richard Montague Universal grammar . . . . . . . . . . . 373

THEORIA, which invites contributions in all fields of analytic philosophy, is published three times a year. Subscriptions and requests for back numbers should be sent to the publishers, Messrs. C.W.K. Gleerup, Oresundsvägen 1, 222 38, Lund, Sweden. Annual subscription is Skr. 30:- (approx. 6 US \$).

\section{AMERICAN PHILOSOPHICAL QUARTERLY}

\section{Edited by \\ NICHOLAS RESCHER}

Volume 8 /Number 4

October $197 x$

I. NATHAN ROTENSTREICH: The Ontological Status of History

II. ALAN GEWIRTH: The Fustification of Egalitarian Fustice

III. ADOLF GRUNBAUM: Free Will and Laws of Human Behaviour

IV. R. G. SWINBURNE: The Paradoxes of Confirmation - A Survey

V. DOUGLAS ODEGARD: Identity Through Time

VI. DALLAS WILLARD: The Paradox of Logical Psychologism: Husserl's Way Out

\section{ROLF GEORGE: Enthymematic Consequence}

The annual subscription is $\$ 14$ to Institutions, $\$ 8$ to Individuals, which includes the cost of the annual monograph. All back issues are available at a rate of $\$ 4$ to Institutions, $\$ 3$ for Individuals.

\section{PUBLISHED BY BASIL BLACKWELL WITH THE GOOPERATION OF THE UNIVERSITY OF PITTSBURGH}




\section{MIN D}

\section{October 1971}

I. Quine on the Referential Functions of Bound Variables and Quantifiers: C. A. HookeR

II. Decidability and Natural Language: Y. Wriks

III. Mental Structure and the Identity Theory: J. J. CLARKE

IV. Assessing Utilities: D. Golostick

V. Pleasure: Mary A. MCCloskey

VI. Quandary Ethics: E. PINCOFFs

VII. Laws, Coincidences, Counterfactuals and Counter-Identicals: R. A. SHARPE

VIII. Discussions:

Margolis and Vesey on the Location of Sensations: W. A. NunN

Assertion and Postulation in "Material Logic": R. C. PERRY

Malcolm on "Remembering That": S. J. ODELI

Perception and Physiology: P. L. MCKEE

Punishment for Intentions: J. Marshall

On there Being no Necessary and Sufficient Conditions for Knowledge: J. KellenBERGer

Presentness and the Ideal Language: $\mathrm{L}$. ADDIS

Dreaming and Scepticism: J. WoLFE

Memory and Imagination: J. O. URMSON

On the Nature of Sommers' Rule: G. ENGLEBRETSEN

On Bringing Mrs. Foot out of Coventry: A Tribute to D. Nolan Kaiser: K. W. RANKIN A Note on Knowledge and Mistake: I. HINCKFuss

A Note on Knowledge and Mistake

Hare's View of Morality: M. T. THORNTON

Russell's Distinction between the Primary and Secondary Occurrence of Definite Descriptions: C. E. Cassin

IX. New Books

X. Notes

\section{Ideologie}

SOMMARIO DEL N. 150, 1971

Editoriale: Produrre uomini nuovi.

Dizionario teorico-ideologico

Premessa: Dialettica dello scambio esogamico; Futurologia; Lavoro e attivitd; Ominazione; Rozzismo; Scambio non-mercantile; Strutture del lovoro. Voci redatte da GIUSEPPE DI SIENA, FERRUCCIO ROSSI-LANDI, MARIO SABBATINI.

Saggi

AUGUSTO PONZIO: Ideologia della anormalitd linguistica. GORDON POOLE: Alle origini della concezione borghese della donna.

Interventi

IL TRASFORMISMO DEGLI INTELLETTUALI. ROMANO LUPERINI: GIi intellettuali di sinistra e l'ideologia della ricostruzione nel dopoguerra (II).

Testi e documenti

CONTRIBUTI ALL'ELABORAZIONE TEORICO-POLITICA DI UNA PIATTAFORMA MARXISTA-LENINISTA: Premessa; VII. Alcune note sul lavoro politico contadino; VIII. Note sulla questione di Stalin. A cura del CIRCOLO LENIN DI PUGLIA.

Materiali critici

FRANCO FERRINI: Cinema/Politica. GIUSEPPE DI SIENA: Politica e biologismo.

Ideologie è una rivista che si dedica allo studio teorico e storico delle ideologie e alla loro demistificazione dal punto di vista del marxismo-leninismo della nostra epoca. Abbonamento ai quattro numeri del $1971\left(15^{\circ}-18^{\circ}\right)$ : lire 5.000 per l'Estero. I versamenti vanno effettuati sul ccp. 1/11229 intestato a /deologie. Prezzo del n. $15^{\circ}$, lire 1.500 .

Redazione, segretariato amministrazione: via Girolamo Segato 31, 00147 ROMA. 